\title{
Front Matter: Volume 8610
}

, "Front Matter: Volume 8610," Proc. SPIE 8610, Free-Space Laser Communication and Atmospheric Propagation XXV, 861001 (1 April 2013); doi: $10.1117 / 12.2022931$

SPIE. Event: SPIE LASE, 2013, San Francisco, California, United States 


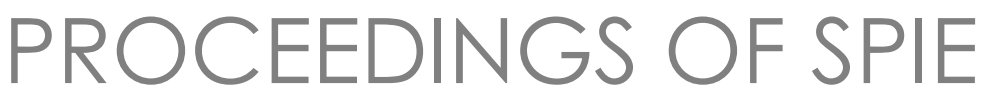

\title{
Free-Space Laser Communication and Atmospheric Propagation XXV
}

\author{
Hamid Hemmati \\ Don M. Boroson \\ Editors
}

5-7 February 2013

San Francisco, California, United States

Sponsored and Published by

SPIE 
The papers included in this volume were part of the technical conference cited on the cover and title page. Papers were selected and subject to review by the editors and conference program committee. Some conference presentations may not be available for publication. The papers published in these proceedings reflect the work and thoughts of the authors and are published herein as submitted. The publisher is not responsible for the validity of the information or for any outcomes resulting from reliance thereon.

Please use the following format to cite material from this book:

Author(s), "Title of Paper," in Free-Space Laser Communication and Atmospheric Propagation XXV, edited by Hamid Hemmati, Don M. Boroson, Proceedings of SPIE Vol. 8610 (SPIE, Bellingham, WA, 2013) Article CID Number.

ISSN: 0277-786X

ISBN: 9780819493798

Published by

SPIE

P.O. Box 10, Bellingham, Washington 98227-0010 USA

Telephone +1 3606763290 (Pacific Time) · Fax +1 3606471445

SPIE.org

Copyright (@ 2013, Society of Photo-Optical Instrumentation Engineers.

Copying of material in this book for internal or personal use, or for the internal or personal use of specific clients, beyond the fair use provisions granted by the U.S. Copyright Law is authorized by SPIE subject to payment of copying fees. The Transactional Reporting Service base fee for this volume is $\$ 18.00$ per article (or portion thereof), which should be paid directly to the Copyright Clearance Center (CCC), 222 Rosewood Drive, Danvers, MA 01923. Payment may also be made electronically through CCC Online at copyright.com. Other copying for republication, resale, advertising or promotion, or any form of systematic or multiple reproduction of any material in this book is prohibited except with permission in writing from the publisher. The CCC fee code is 0277-786X/13/\$18.00.

Printed in the United States of America.

Publication of record for individual papers is online in the SPIE Digital Library.

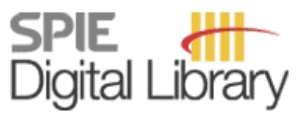

SPIEDigitalLibrary.org

Paper Numbering: Proceedings of SPIE follow an e-First publication model, with papers published first online and then in print and on CD-ROM. Papers are published as they are submitted and meet publication criteria. A unique, consistent, permanent citation identifier (CID) number is assigned to each article at the time of the first publication. Utilization of CIDs allows articles to be fully citable as soon as they are published online, and connects the same identifier to all online, print, and electronic versions of the publication. SPIE uses a six-digit CID article numbering system in which:

- The first four digits correspond to the SPIE volume number.

- The last two digits indicate publication order within the volume using a Base 36 numbering

system employing both numerals and letters. These two-number sets start with 00, 01, 02, 03, 04, $05,06,07,08,09,0 A, 0 B \ldots$. 0Z, followed by 10-1Z, 20-2Z, etc.

The CID Number appears on each page of the manuscript. The complete citation is used on the first page, and an abbreviated version on subsequent pages. Numbers in the index correspond to the last two digits of the six-digit CID Number. 


\section{Contents}

vii Conference Committee

SESSION 1 DEMONSTRATIONS FROM AIR AND SPACE

861002 Status of the lunar laser communication demonstration (Invited Paper) [8610-2]

D. M. Boroson, B. S. Robinson, MIT Lincoln Lab. (United States)

861003 Simultaneous laser ranging and communication from an Earth-based satellite laser ranging station to the Lunar Reconnaissance Orbiter in lunar orbit (Invited Paper) [8610-3]

X. Sun, D. R. Skillman, NASA Goddard Space Flight Ctr. (United States); E. D. Hoffman, Honeywell Technology Solutions Inc. (United States); D. Mao, Sigma Space Corp. (United States); J. F. McGarry, G. A. Neumann, NASA Goddard Space Flight Ctr. (United States); L. McIntire, Catholic Univ. of America (United States); R. S. Zellar, NASA Goddard Space Flight Ctr. (United States); F. M. Davidson, The Johns Hopkins Univ. (United States); W. H. Fong, M. A. Krainak, NASA Goddard Space Flight Ctr. (United States); M. T. Zuber, Massachusetts Institute of Technology (United States); D. E. Smith, NASA Goddard Space Flight Ctr. (United States) and Massachusetts Institute of Technology (United States)

861004 Three years coherent space to ground links: performance results and outlook for the optical ground station equipped with adaptive optics (Invited Paper) [8610-38] M. Gregory, D. Troendle, G. Muehlnikel, F. Heine, Tesat-Spacecom GmbH \& Co. KG (Germany); R. Meyer, M. Lutzer, Deutsches Zentrum für Luft- und Raumfahrt e.V. (Germany); R. Czichy, Synopta GmbH (Switzerland)

\section{SESSION 2 LABORATORY AND PLANNED DEMONSTRATIONS}

86100613 bits per incident photon optical communications demonstration (Invited Paper) [8610-5] W. H. Farr, J. M. Choi, B. Moision, Jet Propulsion Lab. (United States)

861007 Mountain-top-to-valley optical link demonstration as part of a miniature terminal development [8610-6] M. Mosberger, T. Dreischer, M. Bacher, RUAG Space AG (Switzerland)

861008 Wide field-of-view single-mode-fiber coupled laser communication terminal [8610-7] Y. Arimoto, National Institute of Information and Communications Technology (Japan); H. Yoshida, K. Kisara, Japan Aerospace Exploration Agency (Japan)

\section{SESSION 3 POINTING, ACQUISITION, AND TRACKING}

861009 RIN-suppressed ultralow noise interferometric fiber optic gyroscopes (IFOGs) for improving inertial stabilization of space telescopes [8610-10]

F. Hakimi, J. D. Moores, MIT Lincoln Lab. (United States) 
$86100 \mathrm{~A}$ Using a low-noise interferometric fiber optic gyro in a pointing, acquisition, and tracking system [8610-11]

J. Kaufmann, F. Hakimi, D. Boroson, MIT Lincoln Lab. (United States)

\section{SESSION 4 LASER TRANSMITTER/MODULATION}

8610 OF Nonlinearity mitigation of a 40 -Watt 1.55-micron uplink transmitter for lunar laser communications [8610-16]

R. T. Schulein, MIT Lincoln Lab. (United States); R. E. Lafon, NASA Goddard Space Flight Ctr. (United States); M. B. Taylor, P. A. MacKoul, J. J. Carney, M. L. Stevens, B. S. Robinson, S. Constantine, M. M. Willis, MIT Lincoln Lab. (United States); D. W. Peckham, OFS Fitel LLC (United States); B. Zhu, J. M. Fini, OFS Labs. (United States); D. O. Caplan, MIT Lincoln Lab. (United States)

8610 0G Highly efficient and athermal 1550nm-fiber-MOPA-based high power down link laser transmitter for deep space communication [8610-17]

D. Engin, F. Kimpel, J. Burton, H. Cao, B. Mclntosh, M. Storm, S. Gupta, Fibertek, Inc. (United States)

$8610 \mathrm{Ol}$ Orthogonal on-off keying (O3K) for free-space laser communications [8610-19]

S. Faruque, S. Faruque, T. N. Upal, W. Semke, The Univ. of North Dakota (United States)

$8610 \mathrm{JJ}$ The measurement and generation of orbital angular momentum using an optical geometric transformation [8610-20]

M. P. J. Lavery, Univ. of Glasgow (United Kingdom); A. Fraine, Boston Univ. (United States);

D. Roberston, Durham Univ. (United Kingdom); A. Sergienko, Boston Univ. (United States);

J. Courtial, Univ. of Glasgow (United Kingdom); A. E. Wilner, The Univ. of Southern California (United States); M. J. Padgett, Univ. of Glasgow (United Kingdom)

8610 OK A dual format communication modem development for the Laser Communications Relay Demonstration (LCRD) program [8610-21]

M. A. Krainak, E. Luzhanskiy, S. X. Li, S. A. Merritt, A. W. Yu, R. Butler, J. Badgley, L. Thomas, H. Stello, A. Cheng, Q. Nguyen, S. MacPherson, NASA Goddard Space Flight Ctr. (United States)

\section{SESSION 5 GROUND RECEIVER AND TRANSMITTER I}

8610 OM Comparing adaptive optics approaches for NASA LCRD Ground Station \#2 [8610-23] J. B. Stewart, D. V. Murphy, J. D. Moores, A. S. Fletcher, K. M. Bonneau, MIT Lincoln Lab. (United States)

$86100 \mathrm{~N}$ Conceptual design of the adaptive optics system for the laser communication relay demonstration ground station at Table Mountain [8610-24]

L. C. Roberts Jr., N. A. Page, R. S. Burruss, T. N. Truong, S. Dew, M. Troy, Jet Propulsion Lab. (United States)

861000 The Lunar Laser OCTL Terminal (LLOT) [8610-25]

A. Biswas, J. M. Kovalik, Jet Propulsion Lab. (United States) 
8610 OP The Lunar Laser OCTL Terminal (LLOT) optical systems [8610-26]

W. T. Roberts, M. W. Wright, Jet Propulsion Lab. (United States)

$86100 Q$ A post-processing receiver for the lunar laser communications demonstration project [8610-27]

M. Srinivasan, K. Birnbaum, M. Cheng, K. Quirk, Jet Propulsion Lab. (United States)

8610 OR Optical filter assembly for interplanetary optical communications [8610-28]

Y. Chen, H. Hemmati, Jet Propulsion Lab. (United States)

\section{SESSION 7 ATMOSPHERIC CHARACTERIZATION AND ANALYSIS}

8610 OS Effects of atmospheric transmission of high power diode pumped alkali lasers [8610-30] C. A. Rice, G. P. Perram, Air Force Institute of Technology (United States)

8610 OT Measurements of partially spatially coherent laser beam intensity fluctuations propagating through a hot-air turbulence emulator and comparison with both terrestrial and maritime environments [8610-31]

C. Nelson, U.S. Naval Academy (United States) and The Johns Hopkins Univ. (United States); S. Avramov-Zamurovic, U.S. Naval Academy (United States); O. Korotkova, Univ. of Miami (United States); R. Malek-Madani, U.S. Naval Academy (United States); R. Sova, Johns Hopkins Univ. Applied Physics Lab. (United States); F. Davidson, The Johns Hopkins Univ. (United States)

$8610 \mathrm{OU}$ Lidar sensing of the turbulence based on the backscattering enhancement effect [8610-32] A. S. Gurvich, V. A. Kulikov, A.M. Obukhov Institute of Atmospheric Physics (Russian Federation)

8610 OW Determining seeing conditions of a horizontal turbulent optical path with video image analysis [8610-34]

C. C. Wilcox, U.S. Naval Research Lab. (United States); F. Santiago, Sandia National Labs. (United States); S. R. Restaino, K. P. Judd, T. Martinez, J. R. Andrews, U.S. Naval Research Lab. (United States)

$86100 \mathrm{X}$ Efficiency comparison of spatial and spectral diversity techniques for fading mitigation in free-space optical communications over tactical-range distances [8610-35] J. Minet, Univ. of Dayton (United States); M. A. Vorontsov, Univ. of Dayton (United States) and Optonicus (United States); G. Wu, Optonicus (United States); D. Dolfi, Thales Research \& Technology (France)

8610 OY Digital adaptive optics and imaging through deep turbulence [8610-36] M. Aubailly, Univ. of Maryland, College Park (United States) and Optonicus (United States); M. A. Vorontsov, Univ. of Dayton (United States) and Optonicus (United States) 
$86100 Z$ Fading losses on the LCRD free-space optical link due to channel turbulence [8610-37] B. Moision, S. Piazzolla, J. Hamkins, Jet Propulsion Lab. (United States)

Author Index

Proc. of SPIE Vol. $8610861001-6$

Downloaded From: https://www.spiedigitallibrary.org/conference-proceedings-of-spie on 26 Apr 2023 Terms of Use: https://www.spiedigitallibrary.org/terms-of-use 


\title{
Conference Committee
}

\author{
Symposium Chairs
}

Bo Gu, Bos Photonics (United States)

Andreas Tünnermann, Fraunhofer-Institut für Angewandte Optik und Feinmechanik (Germany) and Friedrich-Schiller-Universität Jena (Germany)

Symposium Cochairs

Friedhelm Dorsch, TRUMPF Werkzeugmaschinen GmbH + Company KG (Germany)

Alberto Piqué, U.S. Naval Research Laboratory (United States)

Conference Chairs

Hamid Hemmati, Jet Propulsion Laboratory (United States)

Don M. Boroson, MIT Lincoln Laboratory (United States)

Conference Program Committee

Vincent W. S. Chan, Massachusetts Institute of Technology (United States)

Renny A. Fields, The Aerospace Corporation (United States)

G. Charmaine Gilbreath, U.S. Naval Research Laboratory (United States)

Olga Korotkova, University of Miami (United States)

Michael A. Krainak, NASA Goddard Space Flight Center (United States)

Robert Lange, Tesat-Spacecom GmbH \& Company KG (Germany)

Ronald L. Phillips, Florida Space Institute (United States)

Zoran Sodnik, European Space Research and Technology Center (Netherlands)

Morio Toyoshima, National Institute of Information and Communications Technology (Japan)

Alan Eli Willner, The University of Southern California (United States)

Shiro Yamakawa, Japan Aerospace Exploration Agency (Japan)

\section{Session Chairs}

1 Demonstrations from Air and Space

Hamid Hemmati, Jet Propulsion Laboratory (United States) 
2 Laboratory and Planned Demonstrations

Don M. Boroson, MIT Lincoln Laboratory (United States)

3 Pointing, Acquisition, and Tracking

Don M. Boroson, MIT Lincoln Laboratory (United States)

4 Laser Transmitter/Modulation

Igor Zayer, European Space Operations Center (Germany)

Zoran Sodnik, European Space Research and Technology Center (Netherlands)

5 Ground Receiver and Transmitter I

Keith E. Wilson, Jet Propulsion Laboratory (United States)

6 Ground Receiver and Transmitter II

William H. Farr, Jet Propulsion Laboratory (United States)

$7 \quad$ Atmospheric Characterization and Analysis

Don M. Boroson, MIT Lincoln Laboratory (United States) 